[RAdiocarbon, Vol. 16, No. 3, 1974, P. 381-387]

\title{
UNIVERSITY OF TOKYO RADIOCARBON MEASUREMENTS V
}

\author{
HIROMI KOBAYASHI*, TAEKO HIROSE, MIYOI SUGINO, \\ and NAOTUNE WATANABE**
}

Carbon Dating Laboratory, University of Tokyo, Tokyo, Japan $\dagger$

Most of the ${ }^{14} \mathrm{C}$ measurements reported here were made between August 1970 and August 1972. Chemical treatment of samples and counting technique remain as described previously (R, 1968, v 10, p 144-148; $1971, v 13$, p 97-102). We have added Houtermans-Oeschger type multianode anticoincidence gas proportional counter, manufactured by Tokyo Atomic, Japan. The central counter tube, which has several small holes, $5 \mathrm{~mm}$ diam, is made of aluminized polyethylene foil, $0.06 \mathrm{~mm}$ thick, with $72 \mathrm{~mm}$ inside diam and $300 \mathrm{~mm}$ sensitive length. The external counter tube is made of stainless steel $4 \mathrm{~mm}$ thick, with $93 \mathrm{~mm}$ inside diam and $350 \mathrm{~mm}$ length. The anode wires of both counters are also made of stainless steel $0.05 \mathrm{~mm}$ diam. The counters are surrounded by a paraffin shield $50 \mathrm{~mm}$ thick and encased in a $250 \mathrm{~mm}$ shield of steel on all sides. Acetylene is used as the counting gas at $753.3 \mathrm{~mm} \mathrm{Hg}\left(22 \pm 1^{\circ} \mathrm{C}\right)$. Counting rates of background and $95 \%$ activity of NBS oxalic acid standard were $1.25 \pm$ $0.02 \mathrm{cpm}$ and $14.39 \pm 0.12 \mathrm{cpm}$, respectively.

Ages are calculated using the half-life value 5570 with 1950 as the reference year. The standard deviation quoted includes only $1 \sigma$ counting statistics of background, sample, and standard counts. Maximum ages are given with a limit of 43,900 years BP, corresponding to sample activity less than $3 \sigma$ above background.

\section{ACKNOWLEDGMENTS}

Descriptions, comments, and references to publications are based on information supplied by the submitters. Thanks are due to Tatsuji Hamada, Institute of Physical and Chemical Research, for water with a low tritium content, and to Kazue Hatakeyama for secretarial assistance. The project was partly supported by a Grant in Aid for Fundamental Scientific Research from the Ministry of Education.

\section{SAMPLE DESCRIPTIONS}

I. GEOLOGIC SAMPLES

$$
\text { A. Japan }
$$

\section{TK-82. Soda}

$$
\begin{aligned}
& 15,300 \pm 100 \\
& 13,350 \mathrm{BC}
\end{aligned}
$$

Charred wood embedded in pumice flow bed at Soda, Tsuchiya, Hiratsuka city, Kanagawa Pref (35 20 $0^{\prime} 11^{\prime \prime}$ N, $139^{\circ} 16^{\prime} 4^{\prime \prime}$ E). Coll 1969 by $\mathrm{N}$ Katayama and $\mathrm{T}$ Hamada, Univ Tokyo, and subm 1969 by $\mathrm{N}$ Katayama. Comment $(\mathrm{TH})$ : date younger than expected, probably due to state of preservation in porous flow material overlying clay at the site.

* Department of Anthropology, Faculty of Science, University of Tokyo

** Chairman, Carbon Dating Committee, University of Tokyo

+ Mailing address: c/o Department of Anthropology, Faculty of Science, University of Tokyo, Hongo, Bunkyo-ku, Tokyo, Japan 


\section{TK-87. Lake Shiobara-ko}

$24,500 \pm 400$

Shioya Yaya-gun Tochigi Pref $\left(36^{\circ} 58.7^{\prime} \mathrm{N}, 139^{\circ} 47.3^{\prime} \mathrm{E}\right)$. Coll 1970 by $\mathrm{S}$ Yamada and subm 1970 by F Takai, Univ Tokyo. Comment (A Iijima, Univ Tokyo): same horizon as TK-66 (R, 1971, v 13, p 98).

\section{Ichihino series}

TK-88.

$25,800 \pm 400$

Carbonized tree trunk, $15 \mathrm{~cm}$ diam, from Ito pyroclastic flow, Ichihino, Hiwaki-cho, Kagoshima Pref $\left(31^{\circ} 47^{\prime} 42^{\prime \prime} \mathrm{N}, 130^{\circ} 25^{\prime} 4^{\prime \prime}\right.$ E). Coll by $S$ Yokoyama, Tokyo Univ Educ, and subm 1969 by S Aramaki, Univ Tokyo.

TK-89.

$25,200 \pm 400$

23,250 BC

Charcoal from Ito pyroclastic flow. Same locality as TK-88. Coll 1969 by $S$ Yokoyama and subm 1969 by S Aramaki.

TK-98. Iwato

$\mathbf{2 3 , 5 0 0} \pm 300$

Irat from Tsumaya pyroclastic flow, Iwato, Fukuyama-cho, Kagoshima Pref ( $\left.31^{\circ} 42^{\prime} 34^{\prime \prime} \mathrm{N}, 130^{\circ} 53^{\prime} 27^{\prime \prime} \mathrm{E}\right)$. Coll 1970 by S Yokoyama and subm 1970 by S Aramaki.

\section{TK-104. Shinjo-fumoto}

$26,500 \pm 500$

(liam, from Osumi pumice fall, Shinjofumoto, Tarumizu city, Kagoshima Pref ( $\left.31^{\circ} 25^{\prime} 27^{\prime \prime} \mathrm{N}, 130^{\circ} 45^{\prime} 43^{\prime \prime} \mathrm{E}\right)$. Coll 1971 by S Yokoyama and subm 1971 by S Aramaki.

\section{Southern Chile series}

$$
\text { B. Chile }
$$

\section{TK-70. Puerto Varas 1}

Wood from base of uppermost moraines at depth $3.5 \mathrm{~m}$, exposed in Pan-American hwy cut at crossroads $W$ of Puerto Varas, Llanquihue Prov, Chile $\left(41^{\circ} 19^{\prime} \mathrm{S}, 73^{\circ} 0^{\prime} 50^{\prime \prime} \mathrm{W}\right)$. Coll 1968 by late Shukō Iwatsuka, Univ Tokyo and Atsumasa Okada, Aichi Pref Univ, and subm by Yutaka Sakaguchi, Univ Tokyo. Comment (AO): age is stratigraphically incompatible with measured clate of TK-71, older than expected, because terminal moraines of innermost and predominant row encircling lake Llanquihue, which included this sample, were estimated to correspond to maximum stage of last glaciation (ca 20,000 yr ago).

\section{TK-71. Puerto Varas 2}

$23,300 \pm 300$

Wood from ca $4.5 \mathrm{~m}$ below surface in silt underlying moraines which included TK-70 at almost same locality as Puerto Varas 1. The silt, ex- 
posed in the EW-running hwy cut, consists mostly of water-laid volcanic ash. Coll 1968 by S Iwatsuka and A Okada and subm by Y Sakaguchi.

\section{TK-72. SW of Puerto Montt}

$26,000 \pm 400$

Wood from ca $15 \mathrm{~m}$ below original surface at large exposure facing SW corner of Tenglo I, SW of Puerto Montt, Llanquihue Prov, Chile $\left(41^{\circ} 31^{\prime} 13^{\prime \prime} \mathrm{S}, 73^{\circ} 0^{\prime} 11^{\prime \prime} \mathrm{W}\right)$. Sample was embedded in terminal moraines around Seno (Bay) Reloncavi. Coll 1968 by S Iwatsuka and A Okada and subm by Y Sakaguchi. Comment (AO): date suggests earlier age at maximum stage of last glacial invasion into Seno Reloncavi.

\section{TK-74. SE of Puerto Montt}

$13,900 \pm 120$

Wood from fluvio-glacial silt exposed in a hwy cut, ca $3 \mathrm{~km} \mathrm{SE}$ of Puerto Montt, Llanquihue Prov, Chile $\left(41^{\circ} 29^{\prime} \mathrm{S}, 72^{\circ} 55^{\prime} \mathrm{W}\right)$. Site is on inner side of predominant moraines along $\mathrm{N}$ coast of Seno Reloncavi. Strata are slightly deformed by push of glacier ice, and are locally overlain by gravel. Probably same sample was dated at $15,400 \pm 400 \mathrm{yr}$ (K Segerstrom, 1964). Coll 1968 by S Iwatsuka and A Okada and subm by Y Sakaguchi. Comment (AO): dates suggest advanced stage of piedmont glacier after maximum phase of last glaciation.

\section{Bolivia}

\section{TK-73. Potosi}

$8960 \pm 180$

Peat from middle horizon, 1 to $3 \mathrm{~m}$ thick, ca $10 \mathrm{~m}$ below surface at ca $65 \mathrm{~km} \mathrm{SW}$ of Potosi city, Quijarro, Potosi, Bolivia $\left(19^{\circ} 52^{\prime} \mathrm{S}, 66^{\circ} 06^{\prime}\right.$ $\mathrm{W})$. The peat, probably deposited in warm climate after retreat of valley glacier, is overlain by fluvio-glacial lacustrine sediments. Original surface constitutes wide valley floor, and is dissected, $13 \mathrm{~m}$ deep, by Rio Visicia, upper stream of Rio Yura flowing into the Pilaya, a tributary of Rio La Plata. The site, $+3640 \mathrm{~m}$ alt, is in the Cordillera Real, Cordillera Los Frailes in subdivision, a W branch of E Andean range. Coll 1968 by $\mathrm{S}$ Iwatsuka and A Okada and subm by Y Sakaguchi.

\section{Barbados}

\section{TK-116. St Michael, Barbados}

$18,400 \pm 200$ $16,450 \mathrm{BC}$

Coral (Montastrea annularis) id by $\mathrm{P}$ Enos from Black Rock, $\mathrm{N}$ suburb of Bridgetown, Parish of St Michael, Barbados, West Indies (13 ${ }^{\circ}$ $07^{\prime} \mathrm{N}, 59^{\circ} 38^{\prime} \mathrm{W}$ ). Sample from terrace sediment younger than youngest terrace, 82,000 BP reported by Broecker et al (1968). Coll 1971 by A Sugimura and subm 1972 by A Iijima, Univ Tokyo. Comment (AS): same specimen dates 26,600 \pm 1400 BP (Gak-3547); the difference is unexplained. 
II. ARCHAEOLOGIC SAMPLES

\section{A. Japan}

$18,250 \pm 650$

TK-99. Minatogawa

$16,300 \mathrm{BC}$

Charcoal from clayey soil layer 15 to $16 \mathrm{~m}$ below surface in fissure at limestone quarry, Minatogawa, Gushikami-son, Shimajiri-gun, Okinawa Pref $\left(26^{\circ} 8^{\prime} \mathrm{N}, 127^{\circ} 46^{\prime} \mathrm{E}\right)$. Excavated $1969-1971$ by Research Group for Pleistocene Man in Okinawa. The layer yielded human skeletons including crania. Coll and subm 1970 by $\mathrm{N}$ Watanabe.

\section{TK-100. Takahashi village site}

$$
1770 \pm 140
$$

\section{AD 180}

Charred wood from floor of dwelling pit No. 12 of late Yayoi period at Takahashi village site, Toyota city, Aichi Pref $\left(35^{\circ} 6^{\prime} \mathrm{N}, 137^{\circ} 11^{\prime} \mathrm{E}\right)$. Pottery was of Kakeyama type. Coll 1967 and subm 1970 by N Watanabe.

\section{TK-97. Toro site}

$$
2100 \pm 70
$$

150 BC

Cryptomeria palisade board of dike from $50 \mathrm{~cm}$ below surface of swampy ground at Toro site, Ishida, Shizuoka city, Shizuoka Pref $\left(34^{\circ}\right.$ $\left.57^{\prime} \mathrm{N}, 138^{\circ} 33^{\prime} \mathrm{E}\right)$. Pottery is of late Yayoi type. Coll 1947 and subm 1970 by T Sekino, Univ Tokyo. Comment (TS): date is older than supposed archaeol age. Cf $1950 \pm 130(\mathrm{~N}-70), 1940 \pm 120(\mathrm{~N}-71), 1940 \pm 100(\mathrm{~N}-73)$ : R, 1964, v 6, p 113; $2010 \pm 120$ (N-74a): R, 1966, v 8, p 335; and $1960 \pm$ 80 (Gak-793), $2060 \pm 90$ (Gak-794), $2300 \pm 120$ (Gak-795), $1720 \pm 90$ (Gak-796), $2590 \pm 100$ (Gak-797), $2240 \pm 90$ (Gak-798): R, 1967, v 9, p 55.

\section{Dailaman series}

$$
\text { B. Iran }
$$

A group of ancient tombs from many sites in valley of Dailaman (ca $36^{\circ} 54^{\prime} \mathrm{N}, 49^{\circ} 55^{\prime} \mathrm{E}$ ) in Elburz Mts. Tokyo Univ Iraq-Iran Archaeol Expedition, led by N Egami, excavated some of them in 1960 and 1964. Reports already pub (Egami, Fukai, and Masuda, 1965; 1966; Sono and Fukai, 1968; Fukai and Ikeda, 1971).

\section{TK-95. Charcoal}

\section{$1140 \mathrm{BC}$}

Charcoal from filling of No. 7 tomb in D area on Ghalekuti hill No. II (GHA II-T.7) just above stone lid covering chamber. Coll 1964 by S Miyake and subm 1970 by S Fukai, Univ Tokyo.

\section{TK-96. Wood of coffin}

$1040 \pm 70$

A piece of coffin wood belonging to Islamic period recovered from GHA II-T.4. Coll 1964 by S Miyake and subm 1970 by S Fukai.

\section{Douara Cave I series}

$$
\text { C. Syria }
$$

Charcoal and black humic soil from deposits of Douara Cave I, ca $18 \mathrm{~km} \mathrm{NE}$ of Palmyra, Syria $\left(34^{\circ} 40^{\prime} \mathrm{N}, 38^{\circ} 35^{\prime} \mathrm{E}\right)$. Coll 1970 by $\mathrm{K}$ Endo 
and subm 1971 by H Suzuki. Report was already pub (Suzuki and Takai, 1973).

TK-111a.

TK-111b.

Sample TK-111 was charcoal from hearth of Layer E assoc with Levalloiso-Mousterian industries according to sample submitter, but it resembled black humic soil. TK-111a was not pretreated. TK-111b was pretreated with cold $2 \mathrm{~N} \mathrm{HCl}$ by putting it into a beaker and pouring the acid over it to remove inorganic carbon contaminants. Comment (KE): same sample gave $30,600 \underset{-2100}{+2800}$ (Gak-3537; Suzuki and Takai, 1973, p 143-144).

TK-112.

Black humic soil from Layer $\mathrm{K}$, ca $2.5 \mathrm{~m}$ lower than comparable horizon of TK-111. Sample was pretreated by acid and alkali. Comment (KE): sample of same layer gave 29,600 \pm 1600 (Gak-3535; Suzuki and Takai, 1973).

\section{Lebanon}

TK-113. Tripoli

$2940 \pm 100$

Snail shells from reddish soil in coastal sand dunes, El-Mina, Tripori, Lebanon $\left(34^{\circ} 26^{\prime} \mathrm{N}, 35^{\circ} 49^{\prime} \mathrm{E}\right)$. Coll 1970 by $\mathrm{K}$ Endo and subm 1971 by $\mathrm{H}$ Suzuki. Comment (KE): date of palaeosol intercalated in eolian sands suggests age of sand dune formation in Holocene.

$$
\text { E. Peru }
$$

$530 \pm 80$

TK-93. Ancón

AD 1420

Textile and gourd from Tomb $16,175 \mathrm{~cm}$ below surface, near Bahía de Ancón, Lima, Peru (11 $\left.44^{\prime} \mathrm{S}, 77^{\circ} 10^{\prime} \mathrm{W}\right)$. Coll 1969 by H Vidal, Mus Ancón, and subm 1972 by K Terada, Univ Tokyo. Comment (KT): probably Inca period.

\section{Sechin series}

Archaeol sites at Sechín, central coast, Peru $\left(9^{\circ} 30^{\prime} \mathrm{S}, 78^{\circ} 29^{\prime} \mathrm{W}\right)$. Coll 1971 by L Samaniego, Case Cultura, and subm 1972 by K Terada.

TK-105. Sechín 3rd layer

$1100 \pm 70$

Charcoal from fireplace of dwelling site No. 1.

AD 850

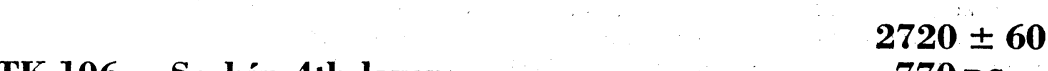

TK-106. Sechín 4th layer

$770 \mathrm{BC}$

Charcoal from fireplace below floor of dwelling site No. 1 . 
TK-107. Sechín 5th layer

Charcoal from layer below 4th layer.

General Comment (KT): dates indicate 2 or 3 periods, including Chavín.

\section{Kotosh series}

Coll 1969 by Univ Tokyo Sci Expedition to the Andes, Kotosh, Peru $\left(9^{\circ} 56^{\prime} \mathrm{S}, 76^{\circ} 16^{\prime} \mathrm{W}\right)$ and subm 1972 by $\mathrm{K}$ Terada, Univ Tokyo. See Izumi and Terada (1972).

\section{TK-108. Kotosh, KM 03-101}

$3000 \pm 80$

Charcoal from Waira-jirca period at K.M mound. Comment (KT): $3800 \pm 110$ (Gak-262), $3780 \pm 90$ (Gak-765), $3200 \pm 80$ (TK-43; R, 1969, v 11, p 514), and $3100 \pm 130$ (N-69-2; R, 1966, v 8, p 336).

\section{TK-109. Kotosh, KM 03-102}

$3360 \pm 160$

\section{TK-110. Kotosh, KM 03-103}

1410 BC

Both were dated with charcoal from Mito period at KT mound. Comment (KT): $3620 \pm 100$ (Gak-766a), $3900 \pm 100$ (Gak-766b) and 3900 \pm 900 (TK-42; R, 1969, v 11, p 514).

\section{Cañamo series}

$$
\text { F. Chile }
$$

Archaeol sites at Cañamo, Iquique, Chile $\left(20^{\circ} 48^{\prime} \mathrm{S}, 70^{\circ} 12^{\prime} \mathrm{W}\right)$. Coll 1967 by L Núñez, Univ Chile and subm 1970 by K Terada. See Núñez, (1965).

TK-101. Cañamo-3

$$
\begin{array}{r}
1190 \\
\text { AD } 760
\end{array}
$$

Plant fiber of basket, offering to the dead, from tomb No. 15 containing Tiahuanacoid elements.

\section{TK-102. Cañamo-2}

$3960 \pm 80$

Charcoal from lowermost layer of shell mound, preceramic, Stratum 4.

\section{TK-103. Cañamo-1}

Charcoal from uppermost layer of shell mound, agricultural and ceramic, Stratum 1.

\section{REFERENCES}

Broecker, W S et al, 1968, Milankovich hypothesis supported by precise dating of coral reefs and deep-sea sediments: Science, v 159, p 297-300.

Egami, N, Fukai, S, and Masuda, S, 1965, Dailaman I; 1966, Dailaman II: Inst Oriental culture, Univ Tokyo.

Fukai, S and Ikeda, J, 1971, Dailaman IV: Inst Oriental culture, Univ Tokyo. 
Izumi, S and Terada, K, 1972, Excavation at Kotosh, Peru, 1963 and 1966, Univ Tokyo. Kigoshi, Kunihiko, 1967, Gakushuin natural radiocarbon measurements VI: Radiocarbon, v 9, p 43-62.

Kobayashi, H, Matsui, Y, and Suzuki, H, 1971, University of Tokyo radiocarbon measurements IV: Radiocarbon, v 13, p 97-102.

Núñez, A L, 1965, Estudios arqueologicos, v 1, Univ Chile.

Sato, J, Sato, T, Otomori, Y, and Suzuki, H, 1969, University of Tokyo radiocarbon measurements II: Radiocarbon, v 11, p 509-514.

Segerstrom, K, 1964, Quaternary geology of Chile: brief outline: Geol Soc America Bull, v 75, p 157-170.

Sono, $\mathrm{T}$ and Fukai, S, 1968, Dailaman III: Inst Oriental culture, Univ Tokyo.

Suzuki, H and Takai, F (ed), 1973, The Palaeolithic site at Douara cave in Syria, p 143150 .

Yamasaki, F, Hamada, T, and Fujiyama, C, 1964, RIKEN natural radiocarbon measurements I: Radiocarbon, v 6, p 112-115.

1966, RIKEN natural radiocarbon measurements II: Radiocarbon, $v 8$, p 324-339. 